\title{
Clinical trials of new drugs for Alzheimer disease
}

Li-Kai Huang ${ }^{1,2+}$, Shu-Ping Chao ${ }^{1,3+}$ and Chaur-Jong $\mathrm{Hu}^{1,2,4,5^{*}}$

\begin{abstract}
Alzheimer disease (AD) accounts for 60-70\% of dementia cases. Given the seriousness of the disease and continual increase in patient numbers, developing effective therapies to treat AD has become urgent. Presently, the drugs available for AD treatment, including cholinesterase inhibitors and an antagonist of the N-methyl-D-aspartate receptor, can only inhibit dementia symptoms for a limited period of time but cannot stop or reverse disease progression. On the basis of the amyloid hypothesis, many global drug companies have conducted many clinical trials on amyloid clearing therapy but without success. Thus, the amyloid hypothesis may not be completely feasible. The number of anti-amyloid trials decreased in 2019, which might be a turning point. An in-depth and comprehensive understanding of the contribution of amyloid beta and other factors of $A D$ is crucial for developing novel pharmacotherapies.

In ongoing clinical trials, researchers have developed and are testing several possible interventions aimed at various targets, including anti-amyloid and anti-tau interventions, neurotransmitter modification, anti-neuroinflammation and neuroprotection interventions, and cognitive enhancement, and interventions to relieve behavioral psychological symptoms. In this article, we present the current state of clinical trials for AD at clinicaltrials.gov. We reviewed the underlying mechanisms of these trials, tried to understand the reason why prior clinical trials failed, and analyzed the future trend of AD clinical trials.
\end{abstract}

Keywords: Alzheimer disease, Clinical trials of drugs, Neuroinflammation, Neuroprotection, Anti-amyloid, Anti-tau, Cognitive enhancement

\section{Introduction}

The World Alzheimer Report 2015 revealed that 46.8 million people worldwide were living with dementia in 2015 , and the total global societal cost of dementia was estimated to be US $\$ 818$ billion. Alzheimer disease (AD) is the most common dementia type and may account for $60-70 \%$ of dementia cases [1]. AD typically presents as progressive memory decline initially, which is accompanied or followed by other cognitive dysfunctions, such as visuospatial abnormalities, navigation difficulties, executive problems, and language disturbance. These cognitive impairments further affect daily life activities, and

\footnotetext{
* Correspondence: chaurjongh@tmu.edu.tw

${ }^{\dagger}$ Li-Kai Huang and Shu-Ping Chao contributed equally to this work.

'Dementia Center, Department of Neurology, Shuang Ho Hospital, Taipei Medical University, New Taipei City, Taiwan

${ }^{2}$ The PhD Program for Neural Regenerative Medicine, College of Medical Science and Technology, Taipei Medical University, National Health Research Institute, Taipei, Taiwan

Full list of author information is available at the end of the article
}

many behavioral psychological symptoms of dementia (BPSD) usually occur during the disease course.

Pathological evidence regarding AD shows that degeneration in cholinergic neuron-rich regions, namely the nucleus basalis of Meynert, frontal cortex, anterior cingulate cortex, and posterior cingulate cortex $[2,3]$, is associated with memory loss, agitation, and apathy. Acetylcholine (ACh) has been shown to be highly correlated with memory function, including memory encoding, consolidation storage, and the retrieval process [4-6]. Currently, at least three cholinesterase inhibitors (AChEIs) approved by the US Food and Drug Administration (FDA) are being used to treat $\mathrm{AD}$, with some clinical improvement in cognition and global function [7]. However, AChEIs can only improve cognitive symptoms of $\mathrm{AD}$ for a certain period but cannot modify the disease course.

The real causes of AD are still unclear. Two pathological hallmarks of AD exist, in terms of senile plaques, which consist of amyloid fibrils composed of the 
amyloid-beta $(A \beta)$ peptide and neurofibrillary tangles consisting of hyperphosphorylated tau protein [8-10]. Another essential finding is brain atrophy, particularly in the hippocampus [11]. The proposition that $A \beta$ accumulation is the central event in $\mathrm{AD}$ pathogenesis was initially proposed by three independent groups in 1991 [12-14]. All the mutant genes of hereditary, autosomal, and dominant familial $\mathrm{AD}$, including amyloid precursor protein (APP), presenilin 1, and presenilin 2, encode the major proteins involved in amyloid metabolism [14-16]. Patients with trisomy 21 have APP gene locations with more amyloid accumulation and high AD risk in late life because they have one more copy of the APP gene, which results in increased amyloid production [17]. Previous studies have shown that the cerebral deposition of A $\beta$ fibrils can occur decades before an individual shows clinical symptoms [18]. Molecular imaging studies such as those using amyloid positron emission tomography (PET) have shown that $A \beta$ deposition reaches a plateau before brain atrophy can be identified from structural magnetic resonance imaging (MRI) and cognitive symptoms $[15,19]$. The amyloid hypothesis has been the mainstream explanation for $\mathrm{AD}$ pathogenesis for decades, but all the prior clinical trials involving amyloid burden reduction failed (Tables 1and 2).

Tau accumulation, which might be a consequence of neuronal damage, was proposed to begin between $A D$ clinical symptom development and $\mathrm{A} \beta$ accumulation [20]. Neurofibrillary tangles and quantitative neuronal loss, but not amyloid plaques, have been found to correlate with disease severity and dementia duration [21-23]. Moreover, PET studies have shown that the spatial patterns of tau tracer binding are closely linked to neurodegeneration patterns and the clinical presentation in patients with AD [24]. Recently, biomarkers of amyloid, tau, and neurodegeneration were used for precisely diagnosing $\mathrm{AD}[25]$.

Furthermore, the brains of patients with AD exhibited evidence of sustained inflammation. A $\beta$ itself acts as a proinflammatory agent, activating many inflammatory components. In the early stages of $\mathrm{AD}$, initial microglial activation may serve a protective role (anti-neuroinflammatory), whereby it tries to clear the amyloid and release nerve growth factors. However, when $A \beta$ or other toxic products over-accumulate, proinflammatory phenotypes are activated, which damage the neurons [26]. Moreover, the inflammatory response has been observed in many studies of postmortem tissues of patients with $\mathrm{AD}$ $[27,28]$. Neuronal death or brain atrophy induced by amyloid, tau, and neuroinflammation might be prevented with neuroprotective therapies, which include suppressing excitable amino acid signaling pathways, free radical scavengers, and regeneration enhancers (Table 3) [29]. In addition to potentially disease-modifying therapies, many clinical trials focusing on symptomatic treatment, including enhancing cognitive functions and relieving BPSD, are ongoing (Table 3). In summary, molecular and clinical events occur subsequently in the disease course of AD. All such events are targets of the ongoing clinical trials of interventions for different $A D$ stages (Fig. 1). The number of phase 3 trials for antiamyloid therapy decreased in 2019 (Fig. 2). The lists of early-phase trials show a diverse trend (Fig. 3).

\section{Anti-amyloid therapy}

A few approaches reduce the amyloid burden have been developed. $A \beta$ is produced from APP, which is digested by gamma-secretase and beta-secretase [30-32]. Both gamma-secretase and beta-secretase inhibitors have been the targets of new drug development $[33,34] . \mathrm{A} \beta$ is degraded by a few enzymes, including neprilysin, and has also been considered for new drug development $[35,36]$. Removing $A \beta$ through immunotherapy is also a reasonable strategy.

In 2019, nine phase 3 trials for eight drugs targeting amyloid are underway. Two of these enrolled patients with preclinical $\mathrm{AD}$; one trial required positive amyloid PET, and the other required genetic mutation or strong genetic risks. Four trials enrolled patients with

Table 1 Failed phase 3 trials on anti-amyloid therapy in AD since 2016

\begin{tabular}{llllll}
\hline Year & Drug & Mechanism of action & Participants & Main reasons for failure & Remarks \\
\hline 2016 & Solanezumab & Monoclonal antibody & Mild AD & Lack of efficacy & Strategic \\
& Solanezumab & Monoclonal antibody & Prodromal AD & Lack of efficacy & Worsens cognition \\
& Verubecestat & BACE inhibitor & Mild to moderate AD & Lack of efficacy & Worsens cognition \\
& Verubecestat & BACE inhibitor & Prodromal AD & Toxicity & Worsens cognition \\
& Atabecestat & BACE inhibitor & Preclinical AD & Lack of efficacy & Worsens cognition \\
& Lanabecestat & BACE inhibitor & Early AD & Lack of efficacy & Lack of efficacy \\
& Lanabecestat & BACE inhibitor & Mild AD & Lack of efficacy & Worsens cognition \\
\hline
\end{tabular}




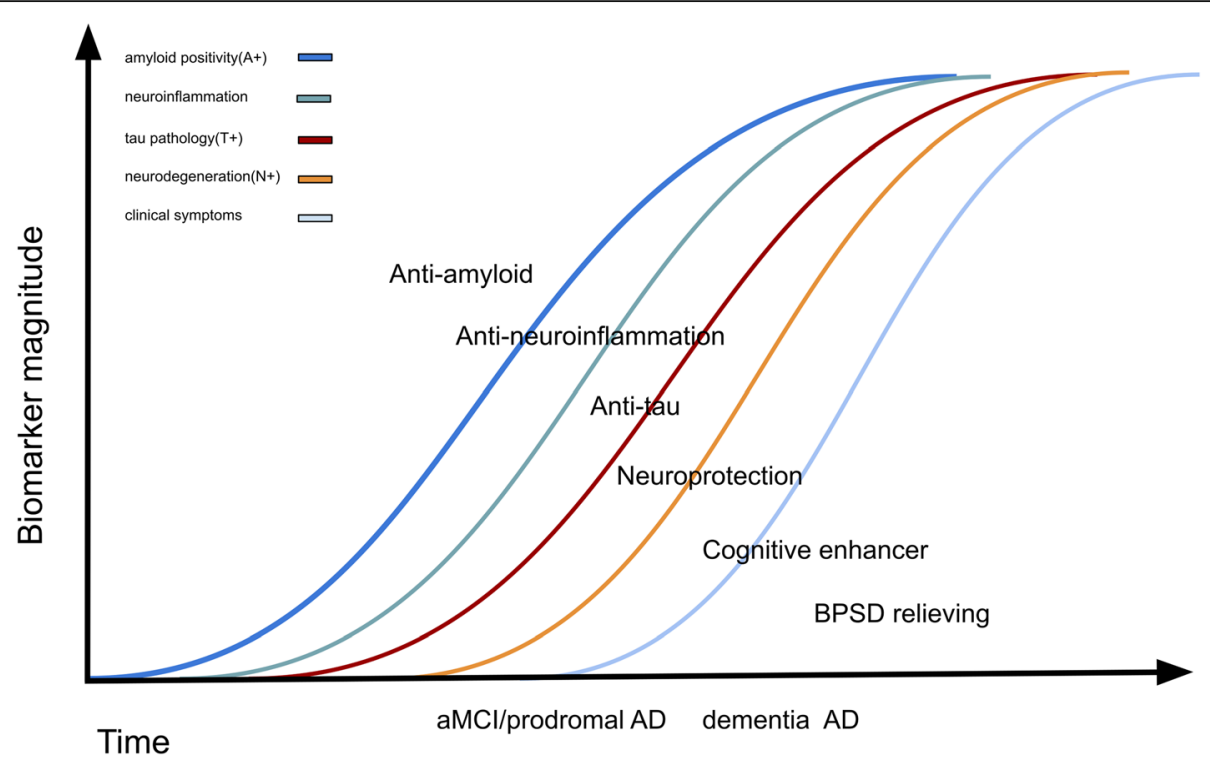

Fig. 1 On the basis of the amyloid hypothesis, the consequent events of pathophysiology and clinical course are amyloid accumulation, neuroinflammation, tau accumulation, brain metabolism dysfunction, brain atrophy, cognitive decline (from mild cognitive impairment to dementia), and dementia symptom development. New drugs should target at least one of these events

prodromal AD with positive biomarkers, with one trial for prodromal and mild AD and two for mild to moderate stages of AD-related dementia. The inclusion criteria for these trials were positive amyloid PET or cerebrospinal fluid (CSF) biomarker results showing evidence of early AD. Such results consisted of reduced CSF A $\beta-42$, increased CSF tau, and, using the definition given by the National Institute on Aging at National Institutes of Health and the Alzheimer's Association (NIA-AA), a diagnosis of mild cognitive impairment (MCI) due to $\mathrm{AD}$ (MCI-AD) or mild dementia due to AD. No ongoing drug trials have enrolled patients with advanced AD, which reflects the present consensus that anti-amyloid therapy is not beneficial for patients in the late stage of AD. Compared with 2017 and 2018 (Fig. 2, Table 2), the number of anti-amyloid phase 3 drug trials was lower in 2019, and anti-amyloid trials have also moved to the early stages of $\mathrm{AD}$, including the prodromal or even preclinical stage. AD surrogate biomarkers have been used frequently as secondary outcome measures. The most common outcome biomarkers in trials have been CSF amyloid, CSF tau, volumetric MRI, and amyloid PET [37]. AD Composite Score (ADCOMS), which combines scores on items derived from the AD Assessment Scalecognitive subscale (ADAS-cog), clinical dementia rating (CDR) score, and Mini-Mental Status Examination (MMSE), has been a useful measure of cognitive outcome in trials concerning early-stage $\mathrm{AD}$ with limited cognitive deficits [38].

AN-1792 is the first active immunotherapy strategy for $\mathrm{AD}$ that consists of a synthetic full-length $\mathrm{A} \beta$ peptide. In
2002, an AN-1792 trial was terminated. In a phase 2 study, $6 \%$ of patients developed aseptic meningoencephalitis as a side effect [39]. In 2019, only one active immunotherapy trial combined CAD106 and CNP520 to treat individuals with the ApoE4 allele and amyloid burden without cognitive impairment. CAD106 combines multiple copies of $A \beta 1-6$ peptide derived from the $\mathrm{N}$ terminal $B$ cell epitope of $A \beta$, coupled to a $Q \beta$ virus-like particle [40]. CNP520 (umibecestat) is an orally ingested, small-molecule inhibitor of aspartyl protease and betascretase-1 (BACE-1). It is designed to interfere with the upstream process of the amyloid cascade to inhibit $A \beta$ production. The Alzheimer's Prevention Initiative Generation Program (Generation Study 1), which consists of a CAD106 injection arm versus a placebo or oral CNP520 (50 mg) arm versus a placebo, has announced that the CNP520 arm showed a worsening of cognitive function. However, the CAD106 treatment arm is ongoing. Bapineuzumab was the first monoclonal antibody used for passive immunotherapy strategy to target $A \beta$ in AD. Further trials were discontinued after the first two trials were completed and yielded no treatment effect on either cognitive or functional outcomes [41]. In 2019, five drug trials were conducted using monoclonal antibody targeting $A \beta$, namely aducanumab, crenezumab, gantenerumab, and solanezumab, and one trial with a combination of gantenerumab and solanezumab. Aducanumab targets aggregated $A \beta$ forms. In the brain, it preferentially binds to parenchymal over vascular amyloid [42]. Studies have shown that amyloid deposition was reduced in all treatment groups at 26 weeks and further 


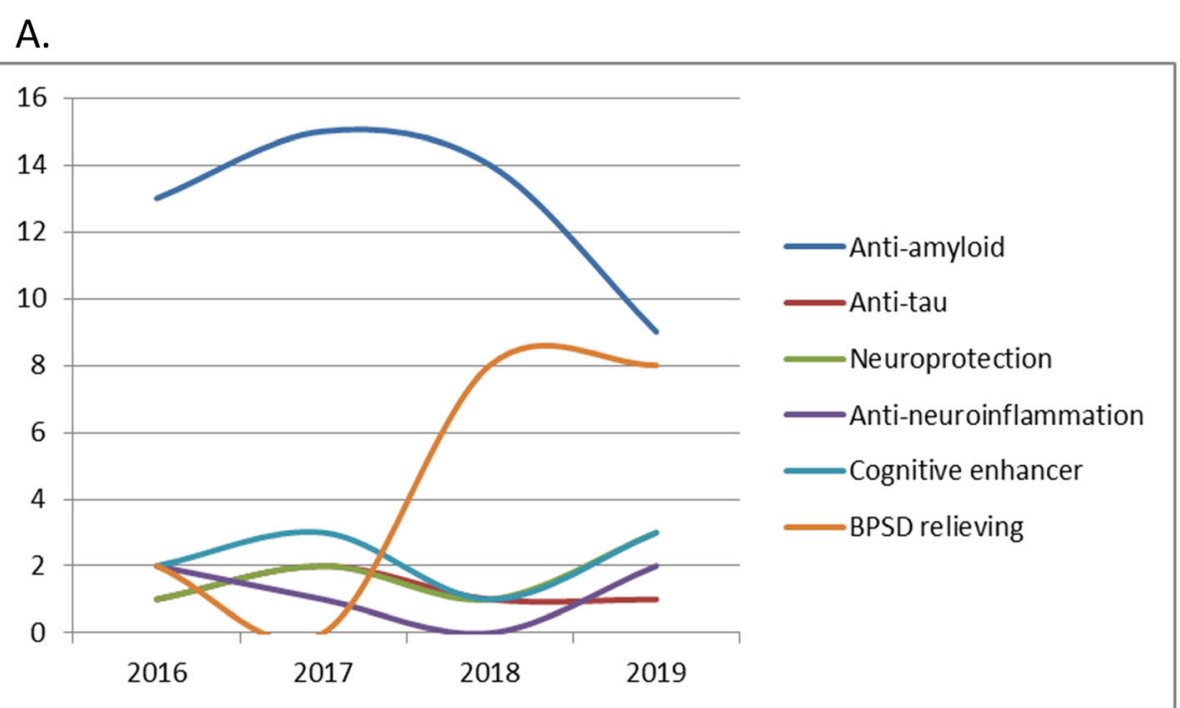

B.

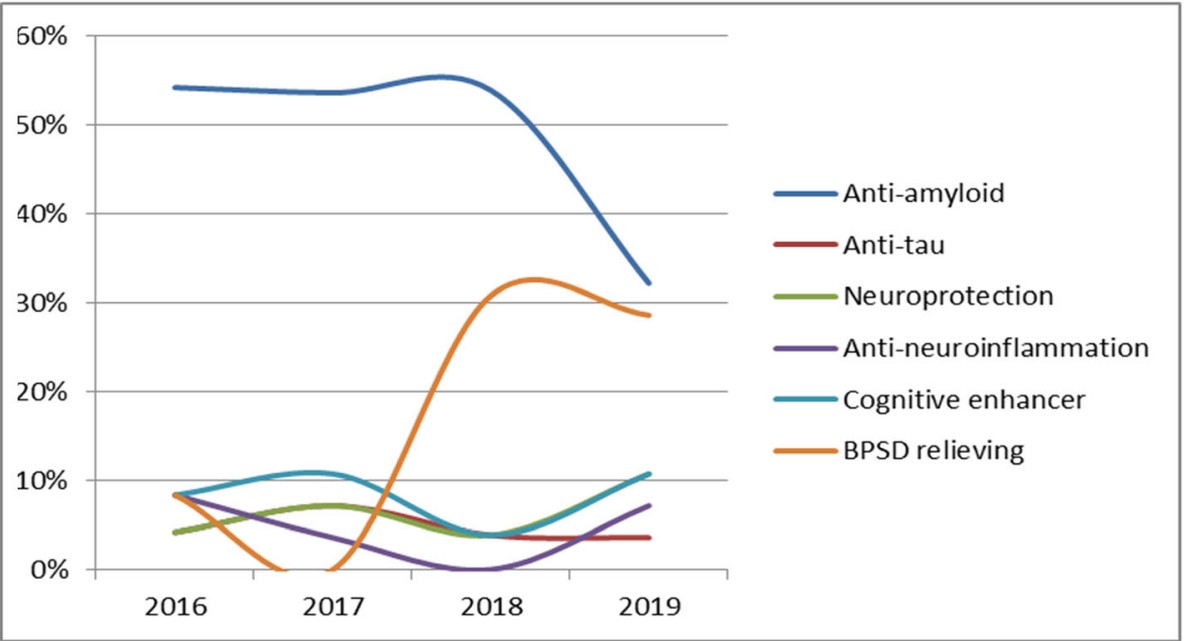

Fig. 2 Trend of phase 3 trials, 2017-2019, according to the event-related categories at ClincalTrials.gov. a Number of phase 3 trials. b Percentage of phase 3 trials

reduced by the end of the first year. Additionally, amyloid was cleared from the six cortical regions of interest, namely the frontal, parietal, lateral temporal, sensorimotor, anterior, and posterior cingulate areas [43]. The most common side effect was amyloid-related imaging abnormalities (ARIA). In ARIA, the white spots in the MRI, which represent vasogenic edema, were mostly found in the ApoE4 carriers and in participants receiving high doses. In 2017 and 2018, the long-term open-label extension phase of the Multiple Dose Study of Aducanumab (BIIB037) (Recombinant, Fully Human Anti-A $\beta$ IgG1 mAb) in Participants With Prodromal or Mild Alzheimer's Disease (PRIME study), which is a phase $1 \mathrm{~b}$ study evaluating the safety, tolerability, and pharmacokinetics/pharmacodynamics of aducanumab in patients with prodromal/mild AD aged 50-90 years with positive amyloid PET scan, was reported to be continuing to show dose-dependent amyloid removal and also slowing cognitive decline. However, in March 2019, Biogen and Eisai announced the termination of the phase $3 \mathrm{EN}$ GAGE (221 AD301 Phase 3 Study of Aducanumab (BIIB037) in Early Alzheimer's Disease) and EMERGE (221 AD302 Phase 3 Study of Aducanumab (BIIB037) in Early Alzheimer's Disease) trials of aducanumab because a futility analysis concluded that these trials would not reach their primary endpoint-slowing of disease progression as measured by the CDR-Sum of Boxes (CDR$\mathrm{SB})$. The futility analysis was based on data available as of on December 26, 2018 from 1748 patients. However, additional data from these studies became available thereafter and it resulted in a large dataset consisting of a total of 3285 patients, including 2066 with the full 18 

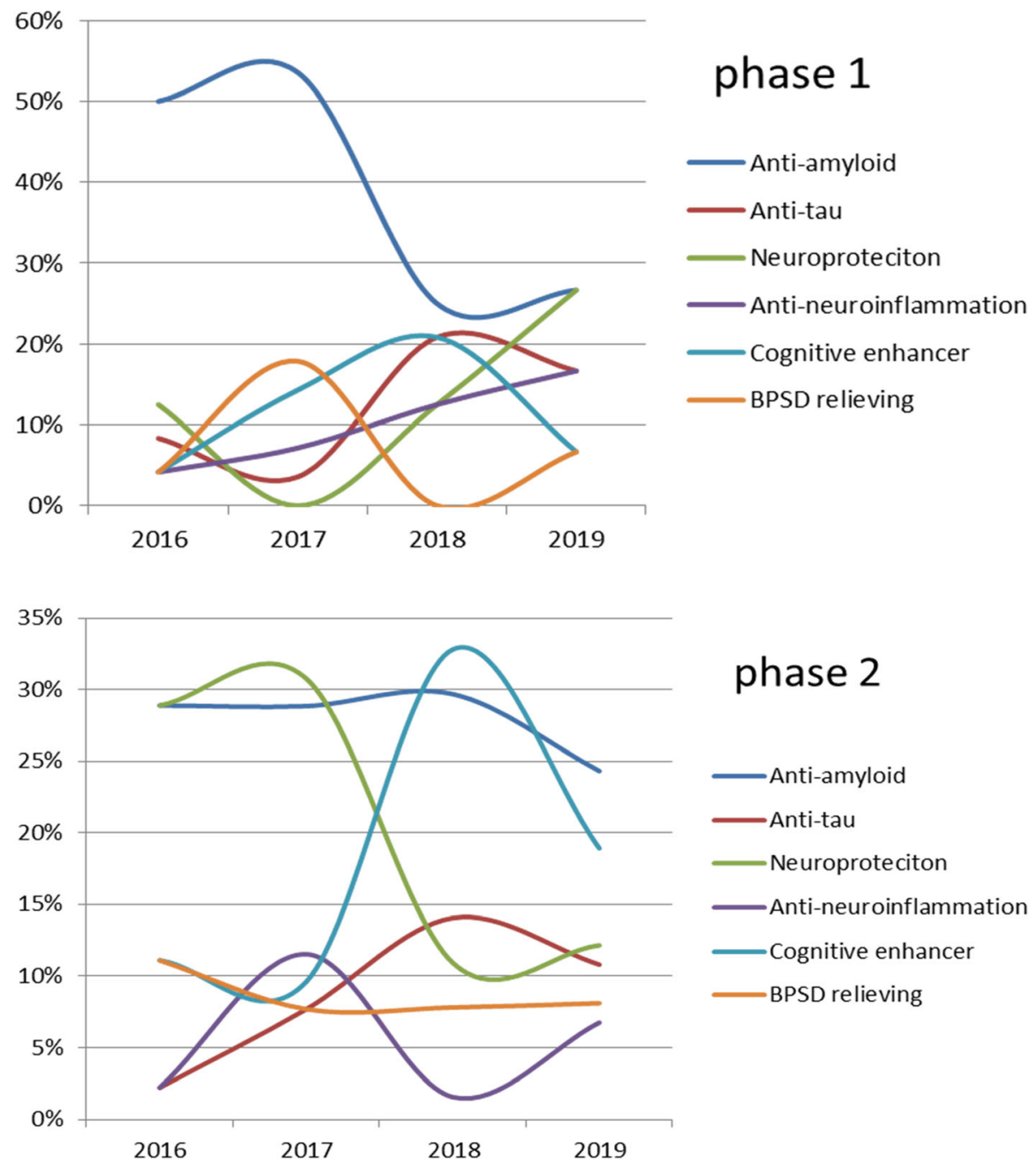

Fig. 3 Trends of phase 1 and phase 2 trials, 2017-2019, according to the event-related categories in ClincalTrials.gov. The percentages of phase 1 and phase 2 trials

months of treatment. The updated analysis revised the results of EMERGE to be statistically significant, especially for the patients treated with a high dose of aducanumab. Those patients showed a significant reduction in decline of global functions from baseline in CDR-SB scores at 78 weeks ( $23 \%$ versus placebo, $P=0.01)$, the ADAS-Cog 13 (27\% versus placebo, $P=0.01$ ), and AD Cooperative Study-Activities of Daily Living Inventory, Mild Cognitive Impairment version (40\% versus placebo, $P=0.001$ ). Imaging of amyloid plaque deposition in EMERGE demonstrated that amyloid plaque burden decreased with low- and high-dose aducanumab compared with placebo at 26 and 78 weeks $(P<0.001)$. The company announced its plan to file a Biologics License Application in early 2020 [44]. Solanezumab is a humanized IgG1 monoclonal antibody that targets the central region of $A \beta$. In phase 3 trials, the Progress of
Mild Alzheimer's Disease in Participants on Solanezumab Versus Placebo (EXPEDITION) 1, EXPEDITION 2, and EXPEDITION 3 studies had enrolled patients with mild to moderate AD with intravenous solanezumab infusions, which failed to show efficacy with regard to cognitive and functional outcomes. Florbetapir PET analysis did not show a reduction in brain amyloid deposits with solanezumab $[45,46]$. Furthermore, solanezumab is being tested in preventive paradigms in the ADCS A4 and DIAN-TU trials (Table 2). Gantenerumab is a completely human recombinant monoclonal IgG1 antibody that binds to both amino-terminal and central regions of $A \beta$. Gantenerumab shows higher affinities for $A \beta$ oligomers and fibrils than for $A \beta$ monomers [47]. The Marguerite RoAD study evaluated monthly subcutaneous injections of gantenerumab in patients with mild AD. Preliminary results from open-label extension studies indicated that 
Table 2 Ongoing phase 3 trials on anti-amyloid therapy in AD in 2019

\begin{tabular}{|c|c|c|c|c|}
\hline Agent & Mechanism of action & $\begin{array}{l}\text { Target type and therapeutic } \\
\text { purpose }\end{array}$ & $\begin{array}{l}\text { ClinicalTrials.gov } \\
\text { identifier }\end{array}$ & Status \\
\hline $\begin{array}{l}\text { Plasma exchange with } \\
\text { albumin } 1 \text { immunoglobulin }\end{array}$ & Plasma exchange & Remove amyloid & NCT01561053 & Completed \\
\hline ALZT-OP1a + ALZT-OP1b & $\begin{array}{l}\text { Mast cell stabilizer, } \\
\text { anti-inflammatory }\end{array}$ & $\begin{array}{l}\text { Amyloid-related and } \\
\text { antineuroinflammatory }\end{array}$ & NCT02547818 & Active, not recruiting \\
\hline ANAVEX2-73 & Anti-tau, Anti-amyloid & $\begin{array}{l}\text { Anti-tau, anti-amyloid, and } \\
\text { antineuroinflammatory }\end{array}$ & NCT03790709 & Recruiting \\
\hline Crenezumab & $\begin{array}{l}\text { Monoclonal antibody } \\
\text { directed at oligomers }\end{array}$ & Remove amyloid & $\begin{array}{l}\text { NCT02670083. } \\
\text { NCT03114657. } \\
\text { NCT03491150 }\end{array}$ & Completed \\
\hline E2609 (elenbecestat) & BACE inhibitor & Reduce amyloid production & $\begin{array}{l}\text { NCT02956486. } \\
\text { NCT03036280 }\end{array}$ & Active, not recruiting \\
\hline Gantenerumab & Monoclonal antibody & Remove amyloid & $\begin{array}{l}\text { NCT02051608. } \\
\text { NCT01224106. } \\
\text { NCT03444870. } \\
\text { NCT03443973 }\end{array}$ & $\begin{array}{l}\text { NCT02051608.NCT01224106 } \\
\text { Active, not recruiting, } \\
\text { NCT03444870.NCT03443973 } \\
\text { Recruiting }\end{array}$ \\
\hline $\begin{array}{l}\text { Gantenerumab and } \\
\text { Solanezumab }\end{array}$ & Monoclonal antibody & $\begin{array}{l}\text { Remove amyloid/reduce } \\
\text { amyloid production }\end{array}$ & NCT01760005 & Recruiting \\
\hline $\begin{array}{l}\text { GV-971 } \\
\text { (sodium oligomannurarate) }\end{array}$ & $\begin{array}{l}A \beta \text { aggregation } \\
\text { inhibitor }\end{array}$ & Amyloid-related & NCT02293915 & Completed \\
\hline Solanezumab & Monoclonal antibody & $\begin{array}{l}\text { Remove amyloid and prevent } \\
\text { aggregation }\end{array}$ & NCT02008357 & Active, not recruiting \\
\hline
\end{tabular}

gantenerumab has an acceptable safety profile at a high dose [48]. Furthermore, gantenerumab is being evaluated in the Safety and Efficacy Study of Gantenerumab in Participants With Early Alzheimer's Disease (GRADUATE) 1, GRADUATE 2, and Dominantly Inherited Alzheimer Network Trials Unit (DIAN-TU) trials (Table 2). Crenezumab is a humanized anti-A $\beta$ monoclonal IgG4 with particular affinity for all pentameric, oligomeric and fibrillary amyloid [49]. Crenezumab is being evaluated in the CREAD (A Study of Crenezumab Versus Placebo to Evaluate the Efficacy and Safety in Participants With Prodromal to Mild Alzheimer's Disease) trials concerning prodromal to mild AD (Table 2). E2609 (elenbecestat) is a BACE-1 inhibitor. A phase $2 \mathrm{~b}$ study on elenbecestat in amyloid-PET-positive patients with $\mathrm{MCI}$, prodromal $\mathrm{AD}$, or mild $\mathrm{AD}$ showed decreased CSF A $\beta$ levels in a dose-dependent manner but no significant improvements in the Alzheimer's Disease Composite Score or CDR-SB score [50, 51]. The efficacy of elenbecestat is being evaluated in the A 24-Month Study to Evaluate the Efficacy and Safety of Elenbecestat in Subjects With Early Alzheimer's Disease (MISSION AD1) and MISSION AD2 trials concerning prodromal AD. These trials will continue until December 2023. GV-971 (sodium oligo-mannurarate) can bind to multiple sites of amyloid, further destabilize and inhibit $A \beta$ aggregation, and then increases A $\beta$ clearance [52]. GV-971 also can reshape gut microbiota and suppress dysbiosis-induced neuroinflammation [53]. A phase 3 study, which began in April 2014, investigated the effects of GV-971 in mild to moderate $\mathrm{AD}$. The primary endpoint is the change in ADAS-Cog 12 score. Reports from this trial showed that GV-971 provides significant cognitive benefits. On November 2, 2019, Shanghai Green Valley Pharmaceuticals announced that China National Medical Product Administration (NMPA) had conditionally approved GV-971 for the treatment of mild to moderate AD [54]. Nilvadipine is a blocker of the dihydropyridine calcium channel. The functions of neuroprotection and anti-inflammation of nilvadipine may contribute to the reduction of $A \beta$ production and the enhancement of A $\beta$ clearance [55].

In 2013, the NILVAD trial measured the efficacy of nilvadipine in people with mild to moderate $A D$. The primary endpoint was ADAS-Cog. The report revealed no change in primary or secondary outcome measures [56].

Although amyloid plaques are regarded as a pathological hallmark of $\mathrm{AD}$, the causal relationship between amyloid deposition and neurodegeneration was unclear for a long time. $A \beta$ has widespread distribution through the brain and body, even in cognitively normal individuals. Soluble A $\beta$ exerts a physiological function, modulating synaptic function and facilitating neuronal growth; furthermore, $A \beta$ protects the brain from infections, repairs leaks in the blood-brain barrier, and promotes recovery from injury $[57,58]$. A study involving cognitively healthy adults showed that $A \beta$ in CSF or the hippocampus increases after sleep deprivation or slowwave sleep disruption, which indicates the complexity of A $\beta$ kinetics [59, 60, 61]. Disease-modifying agents for 
Table 3 Ongoing phase 3 trials on nonanti-amyloid therapy in AD in 2019

\begin{tabular}{|c|c|c|c|c|}
\hline Agent & Mechanism of action & Target type and therapeutic purpose & NCT number & Status \\
\hline$A C-1204$ & Induction of ketosis & $\begin{array}{l}\text { Metabolic; symptomatic } \\
\text { cognitive enhancer }\end{array}$ & NCT01741194 & Completed \\
\hline AGB101 (levetiracetam) & SV2A modulator & $\begin{array}{l}\text { Amyloid-related and } \\
\text { neuroprotective; } \\
\text { disease-modifying therapy }\end{array}$ & NCT03486938 & Recruiting \\
\hline Aripiprazole & $\begin{array}{l}\text { Partial agonist at dopamine D2 } \\
\text { and 5-HT } 1 \mathrm{~A} \text { receptors }\end{array}$ & $\begin{array}{l}\text { Neurotransmitter based; } \\
\text { symptomatic cognitive } \\
\text { enhancer }\end{array}$ & NCT02168920 & Terminated \\
\hline \multirow[t]{4}{*}{ AVP-786 } & $\begin{array}{l}\text { Sigma-1 receptor agonist, } \\
\text { NMDA receptor antagonist }\end{array}$ & $\begin{array}{l}\text { Neurotransmitter based; } \\
\text { BPSD (agitation) }\end{array}$ & NCT03393520 & Recruiting \\
\hline & & & NCT02446132 & Recruiting \\
\hline & & & NCT02442765 & Completed \\
\hline & & & NCT02442778 & Completed \\
\hline AXS-05 & $\begin{array}{l}\text { Sigma-1 receptor agonist; NMDA receptor } \\
\text { antagonist and dopamine-norepinephrine } \\
\text { reuptake inhibitor }\end{array}$ & $\begin{array}{l}\text { Neurotransmitter based; } \\
\text { BPSD (agitation) }\end{array}$ & NCT03226522 & Recruiting \\
\hline \multirow[t]{3}{*}{ Azeliragon } & $\begin{array}{l}\text { Microglial activation inhibitor, } \\
\text { antagonist of the receptor for } \\
\text { advanced glycation end products }\end{array}$ & $\begin{array}{l}\text { Amyloid-related and } \\
\text { antineuroinflammatory; } \\
\text { disease modifying therapy }\end{array}$ & NCT02916056 & Terminated \\
\hline & & & NCT02080364 & Terminated \\
\hline & & & NCT03980730 & Recruiting \\
\hline \multirow[t]{6}{*}{ OPC-34712 (brexpiprazole) } & $\begin{array}{l}\text { A partial agonist at serotonin } \\
5 \text {-hydroxytryptamine } 1 \mathrm{~A} \text { and dopamine } \\
\text { D2 receptors and an antagonist at } \\
\text { serotonin 5-hydroxytryptamine } 2 \mathrm{~A}\end{array}$ & $\begin{array}{l}\text { Neurotransmitter based; } \\
\text { BPSD (agitation) }\end{array}$ & NCT01922258 & Completed \\
\hline & & & NCT01862640 & Completed \\
\hline & & & NCT03620981 & Recruiting \\
\hline & & & NCT03548584 & Recruiting \\
\hline & & & NCT03594123 & Recruiting \\
\hline & & & NCT03724942 & Recruiting \\
\hline Coconut oil & $\begin{array}{l}\text { Reduction in ADP-ribosylation factor } \\
1 \text { protein expression }\end{array}$ & $\begin{array}{l}\text { Anti-amyloid, antineuroinflammatory, } \\
\text { anti-oxidative, and neuroprotective; } \\
\text { symptomatic cognitive enhancer }\end{array}$ & NCT01883648 & Terminated \\
\hline COR388 & Bacterial protease inhibitor & $\begin{array}{l}\text { Antineuroinflammatory; } \\
\text { disease-modifying therapy }\end{array}$ & NCT03823404 & Recruiting \\
\hline Escitalopram & Serotonin reuptake inhibition & $\begin{array}{l}\text { Neurotransmitter based; } \\
\text { BPSD (agitation) }\end{array}$ & NCT03108846 & Recruiting \\
\hline Gabapentin Enacarbil & $\begin{array}{l}\text { Glutamate receptor-independent } \\
\text { mechanisms }\end{array}$ & $\begin{array}{l}\text { Neurotransmitter based } \\
\text { and neuroprotective; } \\
\text { symptomatic cognitive enhancer }\end{array}$ & NCT03082755 & Recruiting \\
\hline Ginkgo biloba & $\begin{array}{l}\text { Antioxidant and anti-amyloid } \\
\text { aggregation }\end{array}$ & $\begin{array}{l}\text { Antioxidant and anti-amyloid; } \\
\text { symptomatic cognitive enhancer }\end{array}$ & NCT03090516 & Recruiting \\
\hline Guanfacine & $\begin{array}{l}\text { Alpha-2A-adrenoceptor agonist, } \\
\text { a potent 5-HT2B receptor agonist }\end{array}$ & $\begin{array}{l}\text { Neurotransmitter based; } \\
\text { symptomatic cognitive enhancer }\end{array}$ & NCT03116126 & Recruiting \\
\hline Icosapent ethyl (IPE) & $\begin{array}{l}\text { Omega- } 3 \text { fatty acids protect } \\
\text { neurons from disease }\end{array}$ & $\begin{array}{l}\text { Neuroprotective; } \\
\text { disease-modifying therapy }\end{array}$ & NCT02719327 & Recruiting \\
\hline \multirow[t]{4}{*}{ Idalopirdine } & 5-HT6 receptor antagonist & $\begin{array}{l}\text { Neurotransmitter based; } \\
\text { symptomatic cognitive enhancer }\end{array}$ & NCT02006641 & Completed \\
\hline & & & NCT01955161 & Completed \\
\hline & & & NCT02006654 & Completed \\
\hline & & & NCT02079246 & Completed \\
\hline RVT-101 (intepirdine) & 5-HT6 receptor antagonist & $\begin{array}{l}\text { Neurotransmitter based; } \\
\text { symptomatic cognitive enhancer }\end{array}$ & NCT02586909 & Terminated \\
\hline
\end{tabular}


Table 3 Ongoing phase 3 trials on nonanti-amyloid therapy in AD in 2019 (Continued)

\begin{tabular}{|c|c|c|c|c|}
\hline Agent & Mechanism of action & Target type and therapeutic purpose & NCT number & Status \\
\hline & & & NCT02585934 & Completed \\
\hline $\begin{array}{l}\text { Insulin } \\
\text { (Humulin® R U-100) }\end{array}$ & Metabolic & $\begin{array}{l}\text { Metabolic; symptomatic } \\
\text { cognitive enhancer }\end{array}$ & NCT01767909 & Completed \\
\hline ITI-007 (lumateperone) & A potent $5-\mathrm{HT} 2 \mathrm{~A}$ antagonist & $\begin{array}{l}\text { Neurotransmitter based; } \\
\text { symptomatic cognitive enhancer }\end{array}$ & NCT02817906 & Terminated \\
\hline $\begin{array}{l}\text { Losartan, amlodipine, } \\
\text { aerobic exercise training, } \\
\text { and others }\end{array}$ & $\begin{array}{l}\text { Angiotensin II receptor blocker, } \\
\text { calcium channel blocker, } \\
\text { cholesterol agent }\end{array}$ & $\begin{array}{l}\text { Antineuroinflammatory } \\
\text { and metabolic; symptomatic } \\
\text { cognitive enhancer }\end{array}$ & NCT02913664 & Recruiting \\
\hline Masitinib & Selective tyrosine kinase inhibitor & $\begin{array}{l}\text { Antineuroinflammatory; } \\
\text { disease modifying therapy }\end{array}$ & NCT01872598 & $\begin{array}{l}\text { Active, } \\
\text { not recruiting }\end{array}$ \\
\hline \multirow[t]{2}{*}{ Methylphenidate } & Dopamine reuptake inhibitor & $\begin{array}{l}\text { Neurotransmitter based; } \\
\text { BPSD (apathy) }\end{array}$ & NCT03811847 & Recruiting \\
\hline & & & NCT02346201 & Recruiting \\
\hline Mirtazapine & Alpha-1 antagonist & $\begin{array}{l}\text { Neurotransmitter based; } \\
\text { BPSD (agitation) }\end{array}$ & NCT03031184 & Recruiting \\
\hline MK-4305 (suvorexant) & Orexin antagonist & BPSD (sleep) & NCT02750306 & Completed \\
\hline \multirow[t]{3}{*}{ EVP-6124 } & $\begin{array}{l}\text { Selective a7 nicotinic acetylcholine } \\
\text { receptor partial agonist }\end{array}$ & $\begin{array}{l}\text { Cholinergic system; } \\
\text { symptomatic cognitive } \\
\text { enhancer }\end{array}$ & NCT02004392 & Terminated \\
\hline & & & NCT01969136 & Terminated \\
\hline & & & NCT01969123 & Terminated \\
\hline Nabilone & $\begin{array}{l}\text { Agonists at cannabinoid } \\
\text { receptors } 1 \text { and } 2(\mathrm{CB} 1 / 2)\end{array}$ & $\begin{array}{l}\text { Neurotransmitter based; } \\
\text { BPSD (agitation) }\end{array}$ & NCT02351882 & Completed \\
\hline Nilvadipine & $\begin{array}{l}\text { Dihydropyridine calcium } \\
\text { channel blocker }\end{array}$ & $\begin{array}{l}\text { Amyloid-related, neuroprotective, } \\
\text { and antineuroinflammatory; } \\
\text { disease-modifying therapy }\end{array}$ & NCT02017340 & Completed \\
\hline AVP-923 (nuedexta) & $\begin{array}{l}\text { Uncompetitive NMDA glutamate } \\
\text { receptor antagonist, a sigma-1 } \\
\text { receptor agonist, and a serotonin } \\
\text { and norepinephrine reuptake inhibitor }\end{array}$ & $\begin{array}{l}\text { Neurotransmitter based and } \\
\text { neuroprotective; symptomatic } \\
\text { cognitive enhancer }\end{array}$ & NCT01832350 & Unknown \\
\hline \multirow[t]{2}{*}{ Pioglitazone } & $\begin{array}{l}\text { Peroxisome proliferator-activated } \\
\text { receptor gamma (PPAR- } \gamma \text { ) agonists }\end{array}$ & $\begin{array}{l}\text { Antineuroinflammatory and } \\
\text { neuroprotective; symptomatic } \\
\text { cognitive enhancers }\end{array}$ & NCT02284906 & Terminated \\
\hline & & & NCT01931566 & Terminated \\
\hline Troriluzole & Glutamate modulator & $\begin{array}{l}\text { Neuroprotective; disease } \\
\text { modifying therapy }\end{array}$ & NCT03605667 & Recruiting \\
\hline \multirow[t]{3}{*}{ TRx0237 (LMTX) } & $\begin{array}{l}\text { Tau stabilizers and aggregation } \\
\text { inhibitors }\end{array}$ & $\begin{array}{l}\text { Anti-tau; disease-modifying } \\
\text { therapy }\end{array}$ & NCT01689233 & Completed \\
\hline & & & NCT02245568 & Terminated \\
\hline & & & NCT03446001 & Recruiting \\
\hline $\begin{array}{l}\text { Vitamin D3 } \\
\text { (cholecalciferol) }\end{array}$ & $\begin{array}{l}\text { Agonist of vitamin D receptor and } \\
\text { other membrane-based receptors } \\
\text { such as MARRS }\end{array}$ & $\begin{array}{l}\text { Metabolic; symptomatic } \\
\text { cognitive enhancer }\end{array}$ & NCT01409694 & Completed \\
\hline Zolpidem Zoplicone & $\begin{array}{l}\text { Allosteric modulator of } \\
\text { GABA-A receptors }\end{array}$ & $\begin{array}{l}\text { Neurotransmitter based; } \\
\text { BPSD (sleep) }\end{array}$ & NCT03075241 & Recruiting \\
\hline
\end{tabular}

$\mathrm{BPSD}=$ behavioral psychological symptoms of dementia; NMDA = N-methyl-D-aspartate

chronic conditions such as AD should be started as early as possible in the course of the pathophysiology. This might be the key lesson of the prior large-scale antiamyloid trials. Researchers now focus on the prodromal or preclinical stage of $A D$, because $A \beta$ deposition could occur decades earlier than the clinical symptoms of $\mathrm{AD}$ manifest. Trials target the stages of even mild cognitive decline may be too late because the brain has been damaged by $\mathrm{A} \beta$ and some irreversible processes have been initiated. Several BACE inhibitor trials have reported that even participants who receive treatment have worse cognitive functions (Table 1). Moreover, the evidence from a failure of reversal of cognitive declines in amyloid-targeting drug trials supports this assumption; 
for example, patients with $\mathrm{AD}$ in whose brains $\mathrm{A} \beta$ plaques were virtually cleared by anti-amyloid immunotherapy did not show cognitive benefit [62]. However, the newly released results from the EMERGE trial indicate that decreasing amyloid load in the brain is beneficial, which suggests that aducanumab could modify, but not reverse, the disease course, thus slowing cognitive decline. Moreover, the amyloid hypothesis has evolved $[9,10,14,63]$. One concept is that $A \beta$ oligomers might impair neuronal function by causing synaptic dysfunction, inducing mitochondrial dysregulation and affecting microglia [64]. The other lesson of the prior large-scale anti-amyloid trials is the need for further basic research regarding metabolism, molecular structures, immune responses, and amyloid toxicity.

\section{Antineuroinflammation therapy}

Azeliragon is an antagonist of the receptor for advanced glycation end products (RAGE). RAGE regulates multiple physiological effects, including the transport of circulating plasma $A \beta$ to the brain, inflammatory process, oxidation stress, and cerebral blood flow [65]. Two phase 3 clinical trials, a 2-year extension study of azeliragon for patients with $\mathrm{AD}$ (Evaluation of the Efficacy and Safety of Azeliragon (TTP488) in Patients With Mild Alzheimer's Disease, STEADFAST Extension) and a study to evaluate the efficacy and safety of azeliragon for patients with mild $\mathrm{AD}$, were discontinued because those trials failed to achieve their primary endpoints in June 2018. The ongoing phase 3 trial to test the effect of azeliragon on patients with mild $\mathrm{AD}$ and impaired glucose tolerance started on June 27, 2019. It is scheduled to end in July 2023.

AD-4833 (Pioglitazone) is an insulin sensitizer for peroxisome-proliferator-activated receptor gamma (PPAR $\gamma$ ) agonists. It binds to PPAR $\gamma$ to regulate the metabolism of glucose and lipid, and it also mediates the response of microglia to increase $A \beta$ phagocytosis and decrease cytokine release, neuroinflammation, and $A \beta$ levels [66]. A phase 3 clinical trial to qualify the biomarkers for MCI-AD risk and for evaluating the efficacy of pioglitazone in delaying its onset was started in $\mathrm{Au}$ gust 2013. The primary outcome measures included the difference of time to diagnosis of MCI-AD for placebotreated and pioglitazone-treated participants in the lowrisk and high-risk groups. The study was terminated because of lack of efficacy in September 2018. Another phase 3 clinical trial was started in February 2015 to investigate the effect of pioglitazone in high-risk participants with cognitive decline and who had completed the TOMORROW (Biomarker Qualification for Risk of Mild Cognitive Impairment (MCI) Due to Alzheimer's Disease (AD) and Safety and Efficacy Evaluation of Pioglitazone in Delaying Its Onset) study with an adjudicated diagnosis of MCI-AD. The primary outcome measures included the change in the composite score of a broad cognitive test battery. The trial was discontinued in May 2018 because of a lack of efficacy.

\section{Anti-tau therapy}

TRx0237 (LMTX) is a tau aggregation inhibitor. It decreases the level of aggregated tau proteins to alleviate tau-related neuronal damage [67]. A TRx0237 trial exploring the efficacy of TRx0237 in mild AD was initiated in October 2012 and ended in May 2016. The primary outcome measures for the clinical trial were changes in the performance of two scales, the ADAS-cog 11 and the ADCS-ADL 23. The report of this trial revealed that TRx0237 failed to be an add-on treatment for AD [68]. In August 2014, a phase 3 trial was started to evaluate the effect of LMTX in AD or behavioral-variant frontotemporal dementia. It was discontinued in May 2017, and the reason for termination has not been disclosed. The ongoing phase 3 trial on TRx0237 began in January 2018. This trial is intended to compare the efficacy of TRx0237 in different doses in participants with early $\mathrm{AD}$. The primary endpoint is the change in the standardized uptake value ratio based on temporal lobe $18 \mathrm{~F}$ fluorodeoxyglucose PET. This trial is scheduled to continue until December 2020.

AADvac1 is an active vaccine that induces the immune response by targeting multiple key epitopes in pathological forms of tau, thereby inhibiting tau aggregation and decreasing the formation of neurofibrillary tangles $[69,70]$. A phase 2 trial of AADvac1 was started in March 2016 and was scheduled to continue until June 2019. The purpose of this study was to evaluate the safety and efficacy of 24 months of AADvac1 treatment in patients with mild AD. Primary outcome measures were the safety and tolerability of AADvac1 based on adverse effects, vital signs, electrocardiogram, laboratory data, brain MRI, physical and neurological examination, the Columbia suicide severity rating scale, and a review of the patient diary. The trial progress is still unclear.

Zagotenemab (LY3303560) is a passive immunotherapy. It is an anti-tau antibody engineered to capture and neutralize tau aggregate [71]. A phase 1 trial to investigate the safety of LY3303560 in participants with mild AD began in January 2017. The primary endpoint was the number of participants with serious adverse events. The trial was completed on June 5, 2019, but the report has not been provided. An ongoing phase 2 trial of LY3303560 is evaluating the safety and effectiveness of the treatment in patients with early symptomatic $\mathrm{AD}$. The primary outcome measure is the change in the integrated $\mathrm{AD}$ rating scale. The trial is still active with an estimated completion date of August 2021. 


\section{Neuroprotection}

BHV-4157 (troriluzole) is a glutamate modulator. Glutamatergic deregulation may lead to brain cell death or dysfunction through destruction of synaptic function and plasticity, promotion of microglia-mediated neuroinflammation, and the release of $A \beta$ and tau [72]. Through increasing the expression of glutamate transporters, BHV-4157 can reduce synaptic glutamate level and increase the synaptic glutamate absorption. In July 2018, phase 2 and 3 trials were initiated to evaluate the efficacy of BHV-4157 in patients with mild to moderate $\mathrm{AD}$. The primary outcome measure is the change in ADAS-Cog 11. The trials are scheduled to continue until February 2020.

Coconut oil comprises medium-chain fatty acids (MCFAs) with a high amount of medium-chain triglycerides. Coconut oil downregulates the expression of ADP-ribosylation factor 1, thereby inhibiting the secretion and aggregation of $A \beta$ and restraining the expression of APP [73]. MCFAs could be converted into ketone bodies, which are related to the improvement of mitochondrial function and reduction of oxidation [74]. Coconut oil can resist oxidation and neuroprotection. A phase 3 clinical trial to investigate the effect of coconut oil in mild to moderate AD was initiated in June 2013. However, it was terminated in February 2017. The reasons for the termination were funding limitations and a low enrollment rate.

Ginkgo biloba extrat (GBE) might improve cognitive function through multiple mechanisms, including regulating kinase signaling pathways, enhancing vasodilation, affecting neurotransmitter levels, ameliorating cerebrovascular circulation, and neuroplasticity [75]. It blocks certain functions of platelet-activating factor, leading to the inhibition of platelet aggregation, suppression of neuroinflammation, and prevention of cell damage caused by free radicals [75, 76]. Phase 2 and 3 trials to investigate the efficacy of GBE in the treatment of mild to moderate AD began in August 2016. The primary outcomes include changes in the MMSE, ADAS-cog, activities of daily life scale, neuropsychiatric inventory, geriatric depression scale, electroencephalography P300, renal function, liver function, and 1.5 T MRI. The trials are scheduled to continue until March 2020.

\section{Cognitive enhancers}

RVT-101 (intepirdine) is a postsynaptic 5hydroxytryptamine (5-HT) 6 receptor antagonist. The antagonist mediates the balance between excitatory and inhibitory signals through the regulation of GABA and glutamate levels in different neuronal circuits. Moreover, it increases the release of several neurotransmitters, including dopamine, norepinephrine (NE), and ACh [77]. The phase 3 MINDSET clinical trial investigated the effect of intepirdine in patients with mild to moderate $\mathrm{AD}$ receiving donepezil 5 or $10 \mathrm{mg}$ daily. The MINDSET trial was started in October 2015 and was completed in September 2017. The primary outcome measures included changes in the scales of ADAS-cog 11 and ADCS-ADL 23. This study failed to achieve its primary endpoints. However, a statistically significant result in a secondary outcome, an improvement in the clinician interview-based impression of change plus caregiver interview, was observed. A phase 3 MINDSET extension trial was started in April 2016. It investigated the safety of RVT-101 for participants with AD who had completed the RVT-101-3001 study. The primary endpoints included the occurrence of adverse events and changes in physical examinations, vital signs, electrocardiograms, and routine laboratory assessments. The trial was terminated in March 2018 because it did not reach the primary endpoints in study RVT-101-3001.

EVP-6124 is an $\alpha 7$ nicotinic acetylcholine receptor agonist and a 5-HT3 receptor antagonist and mediates the release of multiple neurotransmitters, such as $\gamma$ aminobutyric acid, glutamate, $\mathrm{ACh}$, and dopamine [78, 79]. It improves cognitive performance by enhancing cholinergic neurotransmission. In October 2013, two phase 3 trials enrolled patients with mild to moderate $\mathrm{AD}$ taking an AChEI currently or previously in different countries. The primary outcomes included changes in ADAS-Cog 13 and CDR-SB. In June 2014, a phase 3 trial was started to evaluate the safety of EVP-6124 in patients with AD who completed study EVP-6124-024 or EVP-6124-025. In September 2015, the FDA issued a clinical hold on these three AD studies due to a gastrointestinal adverse effect. The clinical hold on these trials continues.

\section{BPSD-relieving therapy}

AXS-05 is a combination of dextromethorphan (DMP) and bupropion. DMP is an N-methyl-D-aspartate (NMDA) receptor antagonist, a glutamate receptor modulator, a sigma-1 receptor agonist, and an inhibitor of the serotonin and NE transporters. Bupropion is a dopamine-NE reuptake inhibitor and CYP2D6 inhibitor, increasing the pharmacodynamics of DMP [80]. Excessive activity of the NMDA receptor is toxic to cells and accelerates cell death [81]. An ongoing phase 3 trial is investigating the efficacy of AXS-05 on agitation in patients with AD. The primary endpoint is the change in the Cohen-Mansfield Agitation Inventory (CMAI) score.

ITI-007 (lumateperone) is a multitarget-directed ligand. It is a 5-HT2A receptor antagonist, a serotonin reuptake inhibitor, a glutamate GluN2B receptor phosphoprotein modulator, and a presynaptic agonism and postsynaptic antagonism at D2 receptors. It regulates the release, uptake, and delivery of a variety of 
neurotransmitters [82]. A phase 3 trial to evaluate the efficacy of ITI-007 in patients with AD experiencing agitation was initiated in June 2016. The primary outcome measure was the change in CMAI-C. The trial was terminated in December 2018 because it failed to meet its primary endpoint after analyzing prespecified interim data.

Apiprazole is a dopamine D2 agonist, a 5-HT receptor 1A receptor agonist, and a 5-HT2A antagonist, acting as dopamine system stabilizers (DSSs). DSSs reduce dopaminergic neurotransmission when excessive dopamine activity in the mesocortical pathway occurs. Thus, DSSs decrease the hyperactivity of dopaminergic neurons, which mediates psychosis, and DSSs restore the dopamine activity in the cortical regions that are thought to be related to cognitive impairment [83]. Furthermore, aripiprazole improves the $A \beta$-induced reduction of neurite outgrowth. This therapy potentially overcomes the neurotoxicity caused by $A \beta$ in $A D$-related psychosis [84]. A phase 3 clinical trial compared the efficacy of different dosages of aripiprazole in patients with $\mathrm{AD}$ experiencing agitation. The primary outcome endpoint was change in the CMAI. The trial was terminated in March 2016 because it was difficult to enroll participants.

MK-4305 (suvorexant) is a dual antagonist of orexin receptors [85]. The diurnal variation of orexin neuronal activity regulates the circadian rhythm. The orexin system regulates the sleep-wake state due to its role in accelerating and maintaining wakefulness and arousal $[85,86]$. A phase 3 trial investigated the efficacy of suvorexant in patients with mild to moderate AD experiencing insomnia. The trial started in May 2016 and was completed in September 2018. The primary outcome measures included changes in polysomnography (derived total sleep time), prevalence of adverse events, and withdrawal rate caused by adverse events. Merck announced that the results of this trial met the primary and secondary endpoints. Suvorexant is a promising candidate in the treatment of behavioral and psychological symptoms in AD-related dementia.

\section{Conclusions}

Effective or disease-modifying drugs for $\mathrm{AD}$ are still lacking. The molecular and clinical events, including amyloid accumulation, neuroinflammation, tau accumulation, neural degeneration, cognitive decline, and occurrence of behavioral psychological symptoms, develop along with $\mathrm{AD}$ progression. The clinical trials targeting these events are under evaluation. Because the trials of anti-amyloid failed in recent years, the research focus has shifted to populations at prodromal or preclinical stages with positive diagnostic biomarkers. Meanwhile, the amyloid hypothesis has been challenged, and the number of anti-amyloid phase 3 trials was reduced significantly in 2019. The targets of phase 1 and 2 trials are diverse, and the trends show increased targeting of neuroprotection and antineuroinflammation in phase 1 and phase 2 trials, respectively. Chronic progressive disorders usually require two or more drugs to effectively slow down the disease progression. Prospectively, it may be reasonable to conduct trials with "dirty drugs" which have actions at multiple targets, namely anti-amyloid and anti-tau effects, neurotransmitter modification, antineuroinflammatory and neuroprotective effects, and cognitive enhancement.

\section{Acknowledgments \\ This manuscript was edited by Wallace Academic Editing.}

\section{Authors' contributions}

LKH wrote, reviewed the amyloid based interventions; SPC wrote, reviewed the anti-tau therapy, neuroprotection, cognitive enhancers and BPSDrelieving therapy. CJH finalized and approved the manuscript. All authors read and approved the final manuscript.

Funding

Not applicable.

\section{Availability of data and materials}

Data sharing is not applicable to this article because no datasets were generated or analyzed during the current study.

Ethics approval and consent to participate

Not applicable.

\section{Consent for publication}

Not applicable

\section{Competing interests}

The authors declare that they have no competing interests.

\section{Author details}

${ }^{1}$ Dementia Center, Department of Neurology, Shuang Ho Hospital, Taipei Medical University, New Taipei City, Taiwan. ${ }^{2}$ The PhD Program for Neural Regenerative Medicine, College of Medical Science and Technology, Taipei Medical University, National Health Research Institute, Taipei, Taiwan.

${ }^{3}$ Graduate Institute of Biomedical Informatics, College of Medical Science and Technology, Taipei Medical University, Taipei, Taiwan. ${ }^{4}$ Neurology, School of Medicine, College of Medicine, Taipei Medical University, Taipei, Taiwan.

${ }^{5}$ Taipei Neuroscience Institute, Taipei Medical University, Taipei, Taiwan.

Received: 4 October 2019 Accepted: 19 December 2019

Published online: 06 January 2020

References

1. Prince MJ. World Alzheimer report 2015: the global impact of dementia: an analysis of prevalence, incidence, cost and trends. London: Alzheimer's disease international; 2015

2. Rosenberg PB, Nowrangi MA, Lyketsos CG. Neuropsychiatric symptoms in Alzheimer's disease: What might be associated brain circuits? Mol Asp Med. 2015;43-44:25-37

3. Whitehouse PJ, Price DL, Clark AW, Coyle JT, DeLong MR. Alzheimer disease: evidence for selective loss of cholinergic neurons in the nucleus basalis. Ann Neurol. 1981:10(2):122-6.

4. Sitaram N, Weingartner H, Caine ED, Gillin JC. Choline: selective enhancement of serial learning and encoding of low imagery words in man. Life Sci. 1978:22(17):1555-60.

5. Power AE, Vazdarjanova A, McGaugh JL. Muscarinic cholinergic influences in memory consolidation. Neurobiol Learn Mem. 2003:80(3):178-93.

6. Boccia MM, Blake MG, Acosta GB, Baratti CM. Atropine, an anticholinergic drug, impairs memory retrieval of a high consolidated avoidance response in mice. Neurosci Lett. 2003;345(2):97-100. 
7. Raina P, Santaguida P, Ismaila A, Patterson C, Cowan D, Levine M, et al. Effectiveness of cholinesterase inhibitors and memantine for treating dementia: evidence review for a clinical practice guideline. Ann Intern Med. 2008;148(5):379-97.

8. Glenner GG, Wong CW. Alzheimer's disease: initial report of the purification and characterization of a novel cerebrovascular amyloid protein. Biochem Biophys Res Commun. 1984;120(3):885-90.

9. Masters $C L$, Simms G, Weinman NA, Multhaup G, McDonald BL, Beyreuther K. Amyloid plaque core protein in Alzheimer disease and Down syndrome. Proc Natl Acad Sci U S A. 1985;82(12):4245-9.

10. Goedert M, Spillantini MG, Crowther RA. Tau proteins and neurofibrillary degeneration. Brain Pathol (Zurich, Switzerland). 1991;1(4):279-86.

11. De Leon MJ, George AE, Golomb J, Tarshish C, Convit A, Kluger A, et al. Frequency of hippocampal formation atrophy in normal aging and Alzheimer's disease. Neurobiol Aging. 1997;18(1):1-11.

12. Beyreuther $K$, Masters CL. Amyloid precursor protein (APP) and beta A4 amyloid in the etiology of Alzheimer's disease: precursor-product relationships in the derangement of neuronal function. Brain Pathol (Zurich, Switzerland). 1991;1(4):241-51.

13. Hardy J, Allsop D. Amyloid deposition as the central event in the aetiology of Alzheimer's disease. Trends Pharmacol Sci. 1991;12(10):383-8.

14. Selkoe DJ. The molecular pathology of Alzheimer's disease. Neuron. 1991; 6(4):487-98.

15. Kang J, Lemaire HG, Unterbeck A, Salbaum JM, Masters CL, Grzeschik KH, et al. The precursor of Alzheimer's disease amyloid A4 protein resembles a cell-surface receptor. Nature. 1987;325(6106):733-6.

16. Gunawardena S, Yang G, Goldstein LS. Presenilin controls kinesin-1 and dynein function during APP-vesicle transport in vivo. Hum Mol Genet. 2013; 22(19):3828-43.

17. Kolata G. Down syndrome--Alzheimer's linked. Science (New York, NY). 1985; 230(4730):1152-3.

18. Sperling R, Mormino $E$, Johnson K. The evolution of preclinical Alzheimer's disease: implications for prevention trials. Neuron. 2014;84(3):608-22.

19. Mormino EC, Kluth JT, Madison CM, Rabinovici GD, Baker SL, Miller BL, et al. Episodic memory loss is related to hippocampal-mediated betaamyloid deposition in elderly subjects. Brain J Neurol. 2009;132(Pt 5): $1310-23$.

20. Jack CR Jr, Knopman DS, Jagust WJ, Shaw LM, Aisen PS, Weiner MW, et al. Hypothetical model of dynamic biomarkers of the Alzheimer's pathological cascade. Lancet Neurol. 2010;9(1):119-28.

21. Gomez-Isla T, Hollister R, West H, Mui S, Growdon JH, Petersen RC, et al. Neuronal loss correlates with but exceeds neurofibrillary tangles in Alzheimer's disease. Ann Neurol. 1997;41(1):17-24.

22. Arriagada PV, Growdon JH, Hedley-Whyte ET, Hyman BT. Neurofibrillary tangles but not senile plaques parallel duration and severity of Alzheimer's disease. Neurology. 1992:42(3 Pt 1):631-9.

23. Bierer LM, Hof PR, Purohit DP, Carlin L, Schmeidler J, Davis KL, et al. Neocortical neurofibrillary tangles correlate with dementia severity in Alzheimer's disease. Arch Neurol. 1995;52(1):81-8.

24. Okamura N, Yanai K. Applications of tau PET imaging. Nat Rev Neurol. 2017; 13:197.

25. Jack CR Jr, Bennett DA, Blennow K, Carrillo MC, Dunn B, Haeberlein SB, et al. NIA-AA research framework: toward a biological definition of Alzheimer's disease. Alzheimer's Dementia : J Alzheimer's Assoc. 2018; 14(4):535-62.

26. Hamelin L, Lagarde J, Dorothee G, Leroy C, Labit M, Comley RA, et al. Early and protective microglial activation in Alzheimer's disease: a prospective study using 18F-DPA-714 PET imaging. Brain J Neurol. 2016; 139(Pt 4):1252-64

27. Gomez-Nicola D, Boche D. Post-mortem analysis of neuroinflammatory changes in human Alzheimer's disease. Alzheimers Res Ther. 2015;7(1):42.

28. Zimmer ER, Leuzy A, Benedet AL, Breitner J, Gauthier S, Rosa-Neto P. Tracking neuroinflammation in Alzheimer's disease: the role of positron emission tomography imaging. J Neuroinflammation. 2014;11(1):120.

29. Chi H, Chang HY, Sang TK. Neuronal Cell Death Mechanisms in Major Neurodegenerative Diseases. Int J Mol Sci. 2018;19(10).

30. Sisodia SS. Beta-amyloid precursor protein cleavage by a membranebound protease. Proc Natl Acad Sci U S A. 1992;89(13):6075-9.

31. Ikezu T, Trapp BD, Song KS, Schlegel A, Lisanti MP, Okamoto T. Caveolae, plasma membrane microdomains for alpha-secretase-mediated processing of the amyloid precursor protein. J Biol Chem. 1998;273(17):10485-95.
32. Chow W, Mattson MP, Wong PC, Gleichmann M. An overview of APP processing enzymes and products. NeuroMolecular Med. 2010;12(1):1-12.

33. Doody RS, Raman R, Farlow M, Iwatsubo T, Vellas B, Joffe S, et al. A phase 3 trial of semagacestat for treatment of Alzheimer's disease. N Engl J Med. 2013;369(4):341-50.

34. May PC, Dean RA, Lowe SL, Martenyi F, Sheehan SM, Boggs LN, et al. Robust central reduction of amyloid-beta in humans with an orally available, nonpeptidic beta-secretase inhibitor. J Neurosci. 2011;31(46):16507-16.

35. El-Amouri SS, Zhu H, Yu J, Marr R, Verma IM, Kindy MS. Neprilysin: an enzyme candidate to slow the progression of Alzheimer's disease. Am J Pathol. 2008;172(5):1342-54.

36. Mohajeri MH, Wollmer MA, Nitsch RM. A 442 -induced increase in neprilysin is associated with prevention of amyloid plaque formation in vivo. J Biol Chem. 2002;277(38):35460-5.

37. Cummings J, Lee G, Ritter A, Sabbagh M, Zhong K. Alzheimer's disease drug development pipeline: 2019. Alzheimer's Dementia: Transl Res Clin Interv. 2019:5:272-93.

38. Wang J, Logovinsky V, Hendrix SB, Stanworth SH, Perdomo C, Xu L, et al. ADCOMS: a composite clinical outcome for prodromal Alzheimer's disease trials. J Neurol Neurosurg Psychiatry 2016;87(9):993-9.

39. Gilman S, Koller M, Black RS, Jenkins L, Griffith SG, Fox NC, et al. Clinical effects of Abeta immunization (AN1792) in patients with AD in AN interrupted trial. Neurology. 2005:64(9):1553-62.

40. Wiessner $C$, Wiederhold K-H, Tissot AC, Frey P, Danner S, Jacobson LH, et al. The second-generation active $A \beta$ immunotherapy CAD106 reduces amyloid accumulation in APP transgenic mice while minimizing potential side effects. J Neurosci. 2011;31(25):9323-31.

41. Salloway S, Sperling R, Fox NC, Blennow K, Klunk W, Raskind M, et al. Two phase 3 trials of bapineuzumab in mild-to-moderate Alzheimer's disease. N Engl J Med. 2014;370(4):322-33.

42. Goure WF, Krafft GA, Jerecic J, Hefti F. Targeting the proper amyloid-beta neuronal toxins: a path forward for Alzheimer's disease immunotherapeutics. Alzheimers Res Ther. 2014;6(4):42.

43. Sevigny J, Chiao P, Bussiere T, Weinreb PH, Williams L, Maier M, et al. The antibody aducanumab reduces Abeta plaques in Alzheimer's disease. Nature. 2016:537(7618):50-6.

44. Biogen plans regulatory filing for Aducanumab in Alzheimer's Disease based on new analysis of larger dataset from phase 3 studies.

45. Doody RS, Thomas RG, Farlow M, Iwatsubo T, Vellas B, Joffe S, et al. Phase 3 trials of solanezumab for mild-to-moderate Alzheimer's disease. N Engl J Med. 2014;370(4):311-21

46. Honig LS, Vellas B, Woodward M, Boada M, Bullock R, Borrie M, et al. Trial of solanezumab for mild dementia due to Alzheimer's disease. N Engl J Med. 2018;378(4):321-30.

47. Bohrmann B, Baumann K, Benz J, Gerber F, Huber W, Knoflach F, et al. Gantenerumab: a novel human anti-A $\beta$ antibody demonstrates sustained cerebral amyloid- $\beta$ binding and elicits cell-mediated removal of human amyloid- $\beta$. J Alzheimers Dis. 2012;28(1):49-69.

48. Abi-Saab D, Andjelkovic M, Delmar P, Voyle N, Esau N, Lasser RA. The effect of 6 MONTHS'DOSING on the rate of amyloid-related imaging abnormalities (ARIA) in the MARGUERITE ROAD study. Alzheimer's Dementia: J Alzheimer's Assoc. 2017;13(7):P252-P3.

49. Vos SJ, Xiong C, Visser PJ, Jasielec MS, Hassenstab J, Grant EA, et al. Preclinical Alzheimer's disease and its outcome: a longitudinal cohort study. Lancet Neurol. 2013:12(10):957-65.

50. Oneeb M, Gee M, Albala B, editors. Dose-related reductions of CSF amyloid $\beta(1-x)$ by E2609, a novel BACE inhibitor in patients with mild cognitive impairment due to AlzheimerLs disease (AD and mild-moderate $A D$ dementia. 2016 CTAD Meeting; 2016.

51. Murakami K, Irie K. Three structural features of functional food components and herbal medicine with amyloid $\beta 42$ anti-aggregation properties. Molecules. 2019:24(11):2125.

52. Wang $X$, Sun $G$, Feng $T$, Zhang J, Huang $X$, Wang T, et al. Sodium oligomannate therapeutically remodels gut microbiota and suppresses gut bacterial amino acids-shaped neuroinflammation to inhibit Alzheimer's disease progression. Cell Res. 2019:1-17.

53. Green Valley Announces NMPA Approval Of Oligomannate For Mild To Moderate Alzheimer's Disease. http://www.greenvalleypharma.com/En/ Index/pageView/catid/48/id/28.html

54. Paris D, Bachmeier C, Patel N, Quadros A, Volmar CH, Laporte V, et al. Selective antihypertensive dihydropyridines lower Abeta accumulation by 
targeting both the production and the clearance of Abeta across the blood-brain barrier. Mol Med (Cambridge, Mass). 2011;17(3-4):149-62.

55. Lawlor B, Segurado R, Kennelly S, Rikkert MGO, Howard R, Pasquier F, et al. Nilvadipine in mild to moderate Alzheimer disease: a randomised controlled trial. PLoS Med. 2018;15(9):e1002660.

56. Bishop GM, Robinson SR. Physiological roles of amyloid-beta and implications for its removal in Alzheimer's disease. Drugs Aging. 2004; 21(10):621-30.

57. Puzzo D, Gulisano W, Arancio O, Palmeri A. The keystone of Alzheimer pathogenesis might be sought in Abeta physiology. Neuroscience. 2015;307:26-36

58. Shokri-Kojori E, Wang GJ, Wiers CE, Demiral SB, Guo M, Kim SW, et al. Betaamyloid accumulation in the human brain after one night of sleep deprivation. Proc Natl Acad Sci U S A. 2018;115(17):4483-8.

59. Ju YS, Ooms SJ, Sutphen C, Macauley SL, Zangrilli MA, Jerome G, et al. Slow wave sleep disruption increases cerebrospinal fluid amyloid-beta levels. Brain J Neurol. 2017;140(8):2104-11.

60. Lucey BP, Hicks TJ, McLeland JS, Toedebusch CD, Boyd J, Elbert DL, et al. Effect of sleep on overnight cerebrospinal fluid amyloid beta kinetics. Ann Neurol. 2018;83(1):197-204.

61. Holmes C, Boche D, Wilkinson D, Yadegarfar G, Hopkins V, Bayer A, et al. Long-term effects of Abeta42 immunisation in Alzheimer's disease: followup of a randomised, placebo-controlled phase I trial. Lancet (London, England). 2008;372(9634):216-23.

62. Selkoe DJ, Hardy J. The amyloid hypothesis of Alzheimer's disease at 25 years. EMBO Mol Med. 2016;8(6):595-608.

63. Polanco JC, Li C, Bodea LG, Martinez-Marmol R, Meunier FA, Gotz J. Amyloid-beta and tau complexity - towards improved biomarkers and targeted therapies. Nat Rev Neurol. 2018;14(1):22-39.

64. Burstein A, Sabbagh M, Andrews R, Valcarce C, Dunn I, Altstiel L. Development of Azeliragon, an oral small molecule antagonist of the receptor for advanced glycation endproducts, for the potential slowing of loss of cognition in mild Alzheimer's disease. J Prev Alzheimer's Dis. 2018;5(2):149-54.

65. Galimberti D, Scarpini E. Pioglitazone for the treatment of Alzheimer's disease. Expert Opin Investig Drugs. 2017;26(1):97-101.

66. Bakota L, Brandt R. Tau biology and tau-directed therapies for Alzheimer's disease. Drugs. 2016;76(3):301-13.

67. Cummings JL, Tong G, Ballard C. Treatment combinations for Alzheimer's disease: Current and future pharmacotherapy options. J Alzheimer's Dis. 2019(Preprint):1-16.

68. Novak M, Kontsekova E, Zilka N, Novak P. Ten years of tau-targeted immunotherapy: the path walked and the roads ahead. Front Neurosci. 2018;12:798.

69. Chong FP, Ng KY, Koh RY, Chye SM. Tau proteins and tauopathies in Alzheimer's disease. Cell Mol Neurobiol. 2018;38(5):965-80.

70. Congdon EE, Sigurdsson EM. Tau-targeting therapies for Alzheimer disease. Nat Rev Neurol. 2018:14(7):399.

71. Wilkinson ST, Sanacora G. A new generation of antidepressants: an update on the pharmaceutical pipeline for novel and rapid-acting therapeutics in mood disorders based on glutamate/GABA neurotransmitter systems. Drug Discov Today 2018.

72. Bansal A, Kirschner M, Zu L, Cai D, Zhang L. Coconut oil decreases expression of amyloid precursor protein (APP) and secretion of amyloid peptides through inhibition of ADP-ribosylation factor 1 (ARF1). Brain Res. 1704;2019:78-84.

73. Pinto A, Bonucci A, Maggi E, Corsi M, Businaro R. Anti-oxidant and antiinflammatory activity of ketogenic diet: new perspectives for neuroprotection in Alzheimer's disease. Antioxidants. 2018;7(5):63.

74. Yuan Q. Wang C-W, Shi J, Lin Z-x. effects of Ginkgo biloba on dementia: an overview of systematic reviews. J Ethnopharmacol. 2017;195:1-9.

75. Tian J, Liu Y, Chen K. Ginkgo biloba extract in vascular protection: molecular mechanisms and clinical applications. Curr Vasc Pharmacol. 2017; 15(15):532-48.

76. Khoury R, Grysman N, Gold J, Patel K, Grossberg GT. The role of 5 HT6receptor antagonists in Alzheimer's disease: an update. Expert Opin Investig Drugs. 2018;27(6):523-33.

77. Yang T, Xiao T, Sun Q, Wang K. The current agonists and positive allosteric modulators of a7 nAChR for CNS indications in clinical trials. Acta Pharm Sin B. 2017;7(6):611-22.

78. Posadas I, López-Hernández B, Ceña V. Nicotinic receptors in neurodegeneration. Curr Neuropharmacol. 2013;11(3):298-314.
79. Ahmed M, Malik M, Teselink J, Lanctôt KL, Herrmann N. Current agents in development for treating behavioral and psychological symptoms associated with dementia. Drugs Aging. 2019:1-17.

80. Wang R, Reddy PH. Role of glutamate and NMDA receptors in Alzheimer's disease. J Alzheimers Dis. 2017;57(4):1041-8.

81. Kumar B, Kuhad A. Lumateperone: a new treatment approach for neuropsychiatric disorders. Drugs Today (Barcelona, Spain: 1998). 2018; 54(12):713-9.

82. De Deyn PP, Drenth AF, Kremer BP, Oude Voshaar RC, Van Dam D. Aripiprazole in the treatment of Alzheimer's disease. Expert Opin Pharmacother. 2013:14(4):459-74.

83. Park SY, Shin HK, Lee WS, Bae SS, Kim K, Hong KW, et al. Neuroprotection by aripiprazole against $\beta$-amyloid-induced toxicity by P-CK2a activation via inhibition of GSK-3ß. Oncotarget. 2017;8(66):110380.

84. Coleman PJ, Gotter AL, Herring WJ, Winrow CJ, Renger JJ. The discovery of suvorexant, the first orexin receptor drug for insomnia. Annu Rev Pharmacol Toxicol. 2017;57:509-33.

85. Herring WJ, Roth T, Krystal AD, Michelson D. Orexin receptor antagonists for the treatment of insomnia and potential treatment of other neuropsychiatric indications. J Sleep Res. 2019;28(2):e12782.

\section{Publisher's Note}

Springer Nature remains neutral with regard to jurisdictional claims in published maps and institutional affiliations.
Ready to submit your research? Choose BMC and benefit from:

- fast, convenient online submission

- thorough peer review by experienced researchers in your field

- rapid publication on acceptance

- support for research data, including large and complex data types

- gold Open Access which fosters wider collaboration and increased citations

- maximum visibility for your research: over $100 \mathrm{M}$ website views per year

At $\mathrm{BMC}$, research is always in progress.

Learn more biomedcentral.com/submissions 